\title{
Design of a groundwater model to determine the feasibility of extending an artificial salmon-spawning stream: case study for Marx Creek, near Hyder, Alaska
}

\author{
T. P. Nelson • T. E. Lachmar
}

Received: 28 August 2012/ Accepted: 19 June 2013 / Published online: 3 July 2013

(C) The Author(s) 2013. This article is published with open access at Springerlink.com

\begin{abstract}
Marx Creek is a groundwater-fed, artificial salmon-spawning stream near Hyder, Alaska. The purpose of this project was to develop a groundwater flow model to predict baseflow to a proposed 450-m extension of Marx Creek. To accomplish this purpose, water levels were monitored in 20 monitor wells and discharge measurements were recorded from Marx Creek. These data were used to create a three-dimensional groundwater flow model using Visual MODFLOW. Three predictive simulations were run after the model was calibrated to groundwater levels and stream discharge measurements. The proposed extension was added to the calibrated model during the first simulation, resulting in simulated baseflow to the extension stream exceeding simulated baseflow to the existing Marx Creek by $39 \%$. Sections of Marx Creek were removed from the model during the second simulation, resulting in a $5 \%$ increase in simulated baseflow to the extension stream. A $32-\mathrm{cm}$ reduction in the water table was simulated during the third simulation, resulting in an $18 \%$ decrease in simulated baseflow to the extension stream. These modeling results were used by Tongass National Forest personnel to determine that baseflow to the proposed extension would likely be sufficient to provide habitat conducive to salmon spawning. The extension stream was constructed and portions of Marx Creek were decommissioned during the summer of 2008. It was observed that there is comparable or greater discharge in the extension stream than there was
\end{abstract}

T. P. Nelson $(\varangle)$

Sullivan International Group, Inc., 402 N. West Street,

Culpeper, VA 22701, USA

e-mail: tnelson@onesullivan.com

T. E. Lachmar

Department of Geology, Utah State University,

4505 Old Main Hill, Logan, UT 84322, USA in the decommissioned sections of Marx Creek, although neither discharge nor stream stage measurements have yet been collected.

Keywords Groundwater - Groundwater modeling · Chum salmon - Alaska · Tongass National Forest - Artificial salmon-spawning stream

\section{Introduction}

Marx Creek is a groundwater-fed, artificial salmonspawning stream located approximately $7 \mathrm{~km}$ north of Hyder, Alaska (Fig. 1). It was constructed in 1974 and reconstructed in 1985 to increase the amount of spawning habitat available to the area's atypically large chum salmon (Oncorhynchus keta), which weigh an average of 20 pounds and were found to weigh in excess of 38 pounds (USFS 2009). Due to Marx Creek's initial success as a productive salmon-spawning stream, a 500-m extension was constructed onto the original Marx Creek in 1989. However, the extension did not share the same success as the original channel because it was constructed adjacent to the Salmon River, which is supplied by glacial meltwater. Although a flood-control dike separates Marx Creek from the Salmon River, silty water was able to infiltrate through the dike and into Marx Creek during periods of high Salmon River stream stage, resulting in a turbid stream environment that was avoided by chum salmon (USFS 2009).

The field site is located entirely within the Tongass National Forest. The site is approximately $1.1 \mathrm{~km}^{2}$ in area and is located immediately east of the Salmon River. Weirs divide Marx Creek into a series of stream cells, with stream cell 1 representing the headwaters of the creek. Marx Creek 
Fig. 1 Aerial photograph showing upper Marx Creek and the Salmon River braided stream system. The rectangular box outlines the field site and model extent

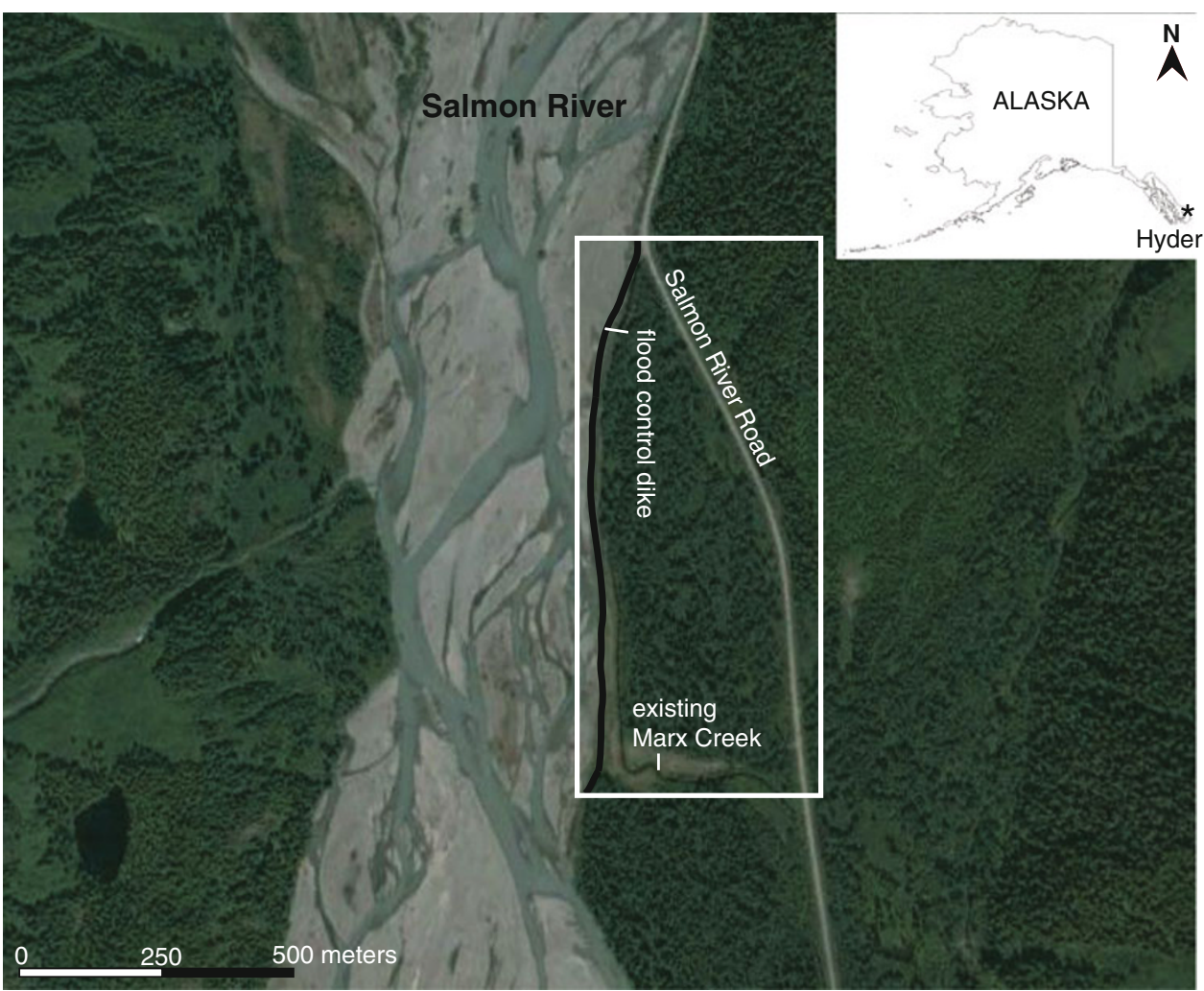

spawning habitat would be provided under such conditions. The results were also used by the Tongass National Forest to assist in deciding whether to decommission portions of upper Marx Creek.

\section{Geologic and hydrologic setting}

Marx Creek is located within the Salmon River Valley, which is a glacial valley that is approximately $1.6 \mathrm{~km}$ wide at the valley bottom. The walls of the valley are steep, and rise up over 1,500 $\mathrm{m}$ in elevation. It is carved through granodiorite bedrock (Buddington 1929), and layers of glacial till and outwash comprise the valley's fill.

The primary direction of groundwater flow in the Salmon River Valley is from north to south, following the valley's elongate orientation. However, there is also a component of flow from the valley margins toward the center of the valley. Although the valley's fill thickness beneath the field site is unknown, it was possible to make an approximate thickness estimate of 50-60 m by creating a topographic profile of the valley.

Marx Creek is an artificial salmon-spawning stream that is fed almost exclusively by upwelling and laterally flowing groundwater-supplied baseflow (Denton 1997). The total length of Marx Creek is approximately $2 \mathrm{~km}$, which is divided into 26 stream cells by wooden weirs. Stream cells vary in length from 6.7 to $335 \mathrm{~m}$, and in width from 4.7 to 


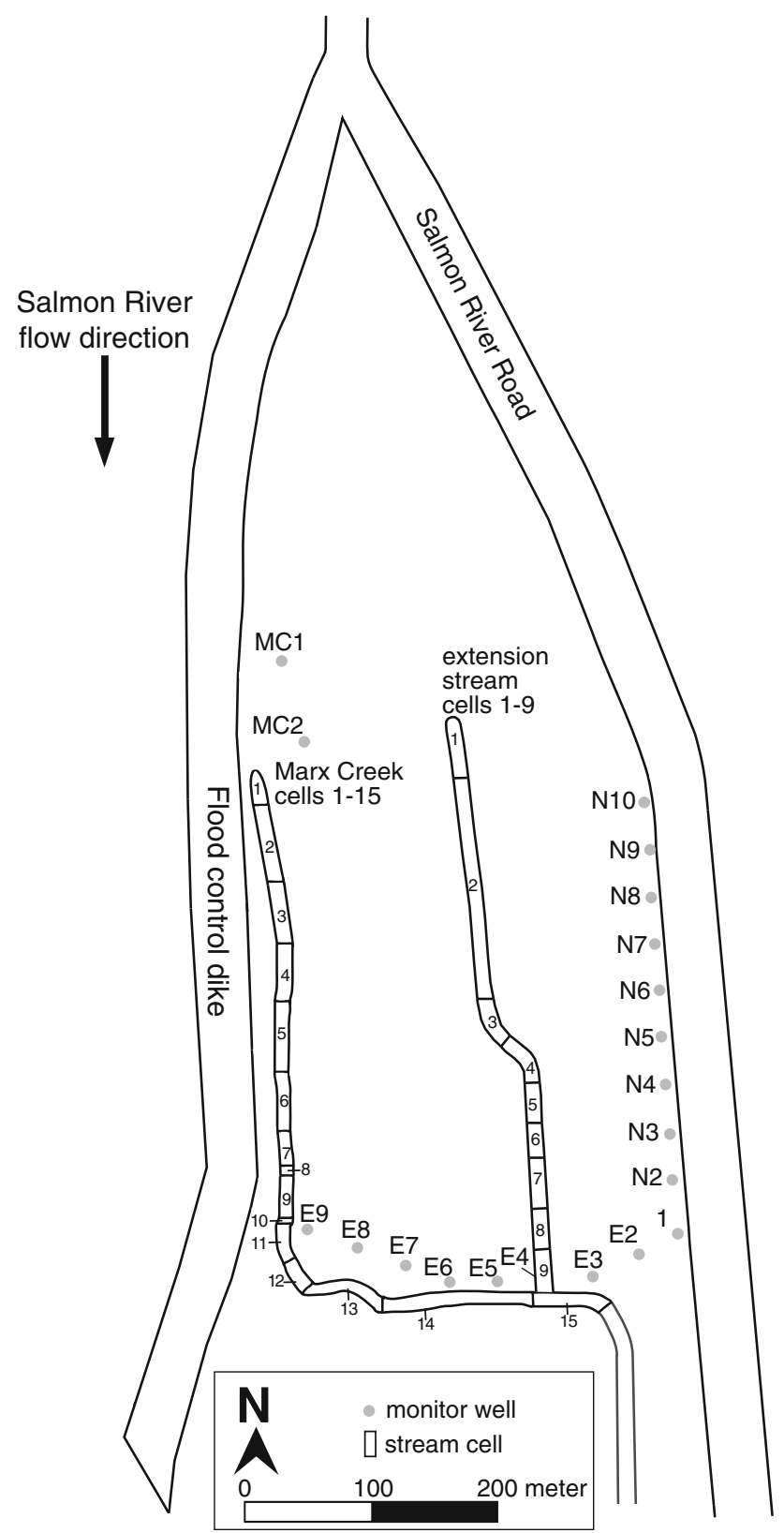

Fig. 2 Map of the field site showing the locations of upper Marx Creek, the extension stream, and monitor wells

$6.45 \mathrm{~m}$ (Denton 1997). The field site encompasses the upper 16 stream cells of Marx Creek (upper Marx Creek).

Marx Creek drains to the Salmon River, which is the primary source of recharge to the groundwater system at the field site, with precipitation acting as a secondary source. The Salmon River is a braided stream with a floodplain $0.4 \mathrm{~km}$ wide. It is fed by meltwater from the Salmon Glacier, and the terminus of this glacier is located $13 \mathrm{~km}$ north of the field site. The Salmon River drains to the Portland Canal at a distance of eight km downstream of the field site. The Portland Canal is a fjord that extends to the Pacific Ocean, and is $110 \mathrm{~km}$ in length. Hyder, Alaska receives an average of $227.5 \mathrm{~cm}$ of precipitation per year, $53.5 \mathrm{~cm}$ of which may be returned to the atmosphere through evapotranspiration (Patric and Black 1968).

\section{Field methodology and results}

Groundwater levels

Twenty monitor wells were installed at the field site in June and July of 2006 (Fig. 2). The wells that were installed along Salmon River Road, near the eastern margin of the site, were designated as $\mathrm{N}$-series wells. Wells that were installed along a dirt access road, north of upper Marx Creek stream cells 13-15, were designated as E-series wells. Two additional monitor wells were installed in the northwestern portion of the field area, and were designated as MC-series wells. Poor access at the field site limited where it was possible to install the monitor wells.

The monitor wells' total depths ranged between 1.27 and $3.51 \mathrm{~m}$ below the ground surface (Nelson 2010). The elevations of the monitor wells were surveyed relative to Well 1. Although it was not possible to determine the exact elevation of Well 1 with a survey benchmark, Google Earth imagery was used to provide a Well 1 elevation estimate of $46 \mathrm{~m}$ above mean sea level.

Two instruments were used to measure and monitor water levels in all of the 20 monitor wells: (1) a steel surveying tape, which was the most reliable and accurate tool, and (2) a Solinst Model 3001 Levelogger with a range of $5 \mathrm{~m}$.

Water levels in all of the monitor wells were measured using the steel surveying tape on three separate occasions. The first set of measurements was collected on 18 July 2006, the second set was collected on either 13 November or 16 December 2006, and the third set was collected on 5 July 2007. These measurements were used to adjust the water levels measured by the Leveloggers, which have a tendency to drift with time.

Water level measurements were recorded twice-daily in all of the monitor wells between 18 July 2006 and 5 July 2007. Water level data recorded between 19 July 2006 and 31 August 2006, which is typically the time of year when chum salmon spawning occurs (Heinl et al. 2004), indicated that water levels fluctuated by an average of $32 \mathrm{~cm}$ during this timeframe, and that total fluctuations ranged between $66 \mathrm{~cm}$ (Well N9) and $20 \mathrm{~cm}$ (Wells E3, E5, and E6) (Nelson 2010).

Stream discharge

Stream discharge measurements were recorded at weirs 1-15 of upper Marx Creek on 2 July 2007. A Marsh 
McBirney Flo-Mate portable flowmeter was used to measure the velocity of water flowing through each weir, and a fiberglass measuring tape was used to measure the crosssectional area of the water column as it flowed through each weir's rectangular spillway. The cross-sectional area of the water column was calculated by multiplying the width of the weir spillway by the height of the water column above the bottom of the spillway. The flow velocity, as measured using a flowmeter, was then multiplied by the cross-sectional area of the water column to calculate the discharge. In addition to the water that flowed through the spillways, water flowed over the tops of several weirs. This additional volume of discharge was accounted for in these situations by collecting velocity and cross-sectional area measurements at several points along the tops of the weirs, as well as at their spillways.

\section{Stream channel dimensions}

Standard engineering surveying equipment was used on 3 July 2007 to measure the relative streambed elevation differences between all of upper Marx Creek's stream cells. Each stream cell's width and water depth were also measured using a fiberglass measuring tape.

The relative elevation difference between the stream stage of upper Marx Creek and the Salmon River was measured at two points along the river on 3 July 2007. The first relative elevation measurement of the Salmon River was taken at a point directly west of the middle of upper Marx Creek's stream cell 2. The second measurement of the Salmon River was taken at a point approximately $30 \mathrm{~m}$ south and due west of well E9. The Salmon River's first stream stage elevation measurement was $0.53 \mathrm{~m}$ lower than the streambed elevation of upper Marx Creek's stream cell 1 , and the second stream stage elevation measurement was $2.21 \mathrm{~m}$ lower than the streambed elevation of stream cell 1 (Nelson 2010).

\section{Groundwater model creation}

Visual MODFLOW version 4.2 (Waterloo Hydrogeologic, Inc. 2006) was used to simulate groundwater flow in the site's saturated, unconsolidated glacial deposits. Visual MODFLOW is a graphical interface for the MODFLOW code (McDonald and Harbaugh 1988), which is a modular, three-dimensional, finite-difference, groundwater flow model.

\section{Discretization of the groundwater system}

The saturated, unconsolidated glacial deposits of the glacial valley were sub-divided into a grid comprised of 38 rows, 32 columns, and 2 layers, resulting in a total of 2,432 grid cells (Fig. 3). The dimensions of the grid cells range between 17.4-29.6 m north-south and 16.8-35.7 m eastwest. The model's total dimensions are $823 \mathrm{~m}$ north-south by $762 \mathrm{~m}$ east-west.

Although glacial valley deposits are heterogeneous, the Marx Creek site's deposits were modeled as a single hydraulic unit due to lack of information on the stratigraphy beneath the site. It is recommended that if significant vertical hydraulic head gradients exist at a site, such as in the Salmon River Valley, that two or more model layers should be used to represent a single hydrostratigraphic unit (Anderson and Woessner 2002). Therefore, to better simulate the valley's vertical groundwater flow component, the site's single hydraulic unit was subdivided into two model layers.

The model's upper layer (layer 1) represents an unconfined aquifer. The thickness of layer 1 was set at a constant $23 \mathrm{~m}$. This value was chosen to aid in model stability, since it is roughly half the estimated thickness of the glacial deposits in the Salmon River Valley.

The ground surface elevations of layer 1 grid cells were assigned using the Kriging method of data interpolation, which is included in Visual MODFLOW version 4.2. Elevations were interpolated based on ground surface elevation measurements taken at the monitor wells. The only grid cells that were manually assigned ground surface elevations were cells that represented upper Marx Creek and the Salmon River. These grid cells were assigned elevations based on surveying measurements collected during upper Marx Creek stream channel surveying, as described above. The grid cells with the highest ground surface elevations in layer 1 are located in the northern portion of the model, and have elevations of approximately $51 \mathrm{~m}$. The grid cells with the lowest ground surface elevations in layer 1 are upper Marx Creek stream cells that are located in the southern portion of the model, and have elevations of approximately $43 \mathrm{~m}$.

The model's lower layer (layer 2) also simulates an unconfined aquifer because it is unknown whether confining units are present beneath the site. The thicknesses of layer 2 grid cells range between 28 and $20 \mathrm{~m}$.

\section{Boundary conditions}

The Marx Creek model includes four constant-head boundaries, a stream boundary, a recharge boundary, and an evapotranspiration boundary. The boundary conditions in the Marx Creek model were assigned as follows: (1) noflow boundary between the unconsolidated glacial deposits and the granodiorite bedrock underlying the glacial valley, (2) specified-flux boundary representing infiltration from precipitation, (3) head-dependent flux boundaries 
Fig. 3 Model grid used for the Marx Creek groundwater model. Vertical and horizontal model scales are in units of feet. Units from the imperial system of measurement were used in designing the model instead of units from the metric system because engineering plans for the extension stream were written in units of feet

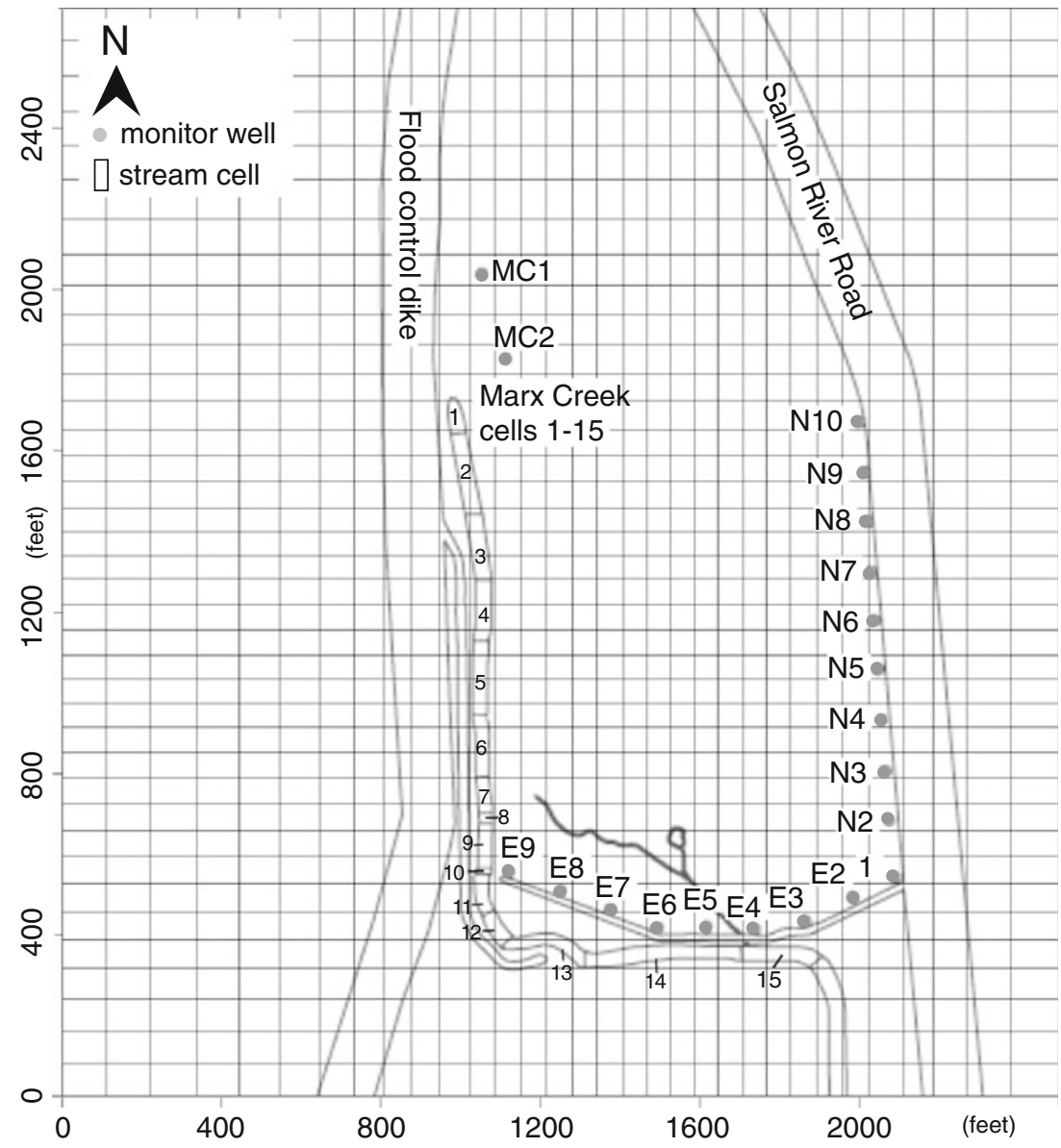

representing seepage to and from streams and evapotranspiration, and (4) constant-head boundaries representing (a) the Salmon River and (b) groundwater flux between the saturated glacial deposits within the model and the saturated glacial deposits outside of the model.

Constant-head boundaries were assigned to all grid cells comprising the northernmost and southernmost rows of the model, and to the easternmost and westernmost columns of the model. The hydraulic head values assigned to the northern, southern, and eastern boundary cells were based on a Kriging-method interpolation of groundwater level data measured in the monitor wells with a steel tape on 18 July 2006. The hydraulic head values assigned to the western boundary cells, which represent the Salmon River, were assigned based on stream stage measurements collected on 3 July 2007.

A stream boundary was assigned to the model to represent upper Marx Creek. This boundary was subdivided into stream segments, with each stream segment comprising 1 of the 16 upper Marx Creek stream cells. Streambed elevations were assigned to these stream segments based on streambed surveying data collected from the site on 3 July 2007. Stream segment widths were assigned based on measurements taken on the same day. Stream segment stage elevations were also assigned to the model, which were determined based on water depth measurements of upper Marx Creek's stream cells on 3 July 2007.

It was necessary to estimate the vertical hydraulic conductivity $\left(K_{\mathrm{v}}\right)$ of the upper Marx Creek streambed material, which was comprised primarily of gravel-sized sediment, because it was not measured in the field. According to Back et al. (1988), the horizontal hydraulic conductivity $\left(K_{\mathrm{h}}\right)$ of gravel-sized sediment typically ranges between 10 and $1,000 \mathrm{~m} /$ day. By assuming a $K_{\mathrm{v}} / K_{\mathrm{h}}$ anisotropic ratio of 0.1 , the $K_{\mathrm{v}}$ of the gravel streambed ranges between 1 and $100 \mathrm{~m} /$ day. An anisotropic ratio of 0.1 was used because, according to Todd (1980), anisotropic ratios of alluvial sediment typically range between 0.1 and 0.5 . The $K_{\mathrm{v}}$ of the streambed material was adjusted within the $1-100 \mathrm{~m} /$ day range during several model simulations to determine a final value to assign to the model's stream sections, and ultimately a value of $30 \mathrm{~m} /$ day was determined to be an adequate representation of the streambed material.

The Marx Creek model was programmed to automatically calculate inflowing stream flow from upstream segments to downstream segments. The first stream segment, representing upper Marx Creek's stream cell 1, was the only segment that was assigned a manual inflowing stream

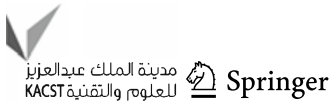


flow value. The value assigned to this segment was $0 \mathrm{~m}^{3} /$ day because it is the headwaters of the stream.

A recharge boundary representing infiltrated precipitation was applied across layer 1 of the model. The value assigned to this boundary was estimated by multiplying the total annual precipitation of Hyder, Alaska, which is approximately $227.5 \mathrm{~cm} /$ year (Patric and Black 1968 ), by the percentage of precipitation that would be expected to infiltrate to the groundwater system. In general, approximately 5-20\% of precipitation infiltrates to the groundwater system, depending on a variety of factors (Waterloo Hydrogeologic, Inc. 2006). A high estimate of $15 \%$ was determined to be applicable to the Marx Creek site, based on the permeable nature of the site's sediment and the gentle slope of the site's ground surface. This yielded a total recharge rate of $34.125 \mathrm{~cm} /$ year, which was applied to the model's recharge boundary.

An evapotranspiration boundary was also applied to layer 1 of the model. Based on potential evapotranspiration measurements from Hyder, Alaska (Patric and Black 1968), an evapotranspiration rate of $53.5 \mathrm{~cm} /$ year was assigned to the model, with an assumed extinction depth of $3 \mathrm{~m}$.

\section{Hydraulic properties}

Although alternating layers of both glacial till and outwash are expected to comprise the unconsolidated deposits beneath the site, the entire Marx Creek model was assigned a uniform hydraulic conductivity value because not enough information was known about the site's stratigraphy to assign layered conductivity values.

Numerous simulations were run to determine an appropriate hydraulic conductivity value for the Marx Creek model. Hydraulic conductivity values representative of glacial till and values representative of glacial outwash were simulated. Ultimately, a hydraulic conductivity value representative of glacial outwash achieved model calibration, which was not surprising because the field site is near the center of the Salmon River Valley. Typically, outwash deposits are thickest near the center of glacial valleys and become thinner or non-existent toward valley margins (Flint 1957). The typical hydraulic conductivity of sand and gravel sediment, such as glacial outwash, can range from 30 to $300 \mathrm{~m} /$ day (Heath 1983). Ultimately, a $K_{\mathrm{h}}$ value of $55 \mathrm{~m} /$ day and a $K_{\mathrm{v}}$ value of $5.5 \mathrm{~m} /$ day were determined to best represent the hydraulic conductivity of the site's sediment.

A specific yield value of 0.2 was also assigned to the model. This value was determined based on typical storativity values of glacial outwash that is comprised primarily of sand- to gravel-sized sediment (Johnson 1967).

\section{Model calibration and simulation}

Model calibration

The Marx Creek model was manually calibrated to hydraulic head values observed in the monitor wells and stream discharge values collected from upper Marx Creek. All of the model's calibration simulations were run under steady-state conditions.

Hydraulic head values observed in the monitor wells on 18 July 2006 were used to calibrate the Marx Creek model. Water level data from this date were used because steel tape measurements were taken at all of the monitor wells on this date. Additionally, 18 July is within the typical spawning peak for summer-run chum salmon, which occurs between mid-July and early September (Heinl et al. 2004).

Root-mean-square error and normalized root-meansquare error (NRMSE) are used to evaluate the calibration of groundwater models (Anderson and Woessner 2002). The Marx Creek model was considered to be calibrated to hydraulic head when a NRMSE of $<10 \%$ was achieved. This criterion was used because a calibration NRMSE of $<10 \%$ is considered to be sufficient for most modeling studies according to Mr. Daniel Gomes, an instructor for the National Ground Water Association's short-course on MODFLOW (D. Gomes short-course lecture 11 June 2009). Ultimately, a hydraulic head calibration NRMSE of $9.6 \%$ was achieved. The maximum head difference between the model-calculated head and the observed head was $-0.81 \mathrm{~m}$ (Well E3), and the mean difference was $-0.23 \mathrm{~m}$. The hydraulic head values observed in the monitor wells on 18 July 2006 and the model-calculated head values from the final calibration simulation can be observed in Table 1. A water-table equipotential map of the calibrated model is included as Fig. 4a.

Stream discharge measurements were also used to calibrate the Marx Creek model. The goal of the discharge calibration was to achieve a NRMSE of $<10 \%$ when comparing model-calculated discharge to observed discharge on 2 July 2007 in all of upper Marx Creek's stream cells. However, to make this comparison it was first necessary to assign all of the model's stream segments as separate zones, which allowed the discharge of individual stream segments to be calculated. Therefore, because the model encompasses stream cells 1-16 of Marx Creek, the model's stream was subdivided into 16 zones. This made it possible to compare the model-calculated discharge of an individual stream segment to the observed discharge of the stream cell being represented by this stream segment.

Calibration of the Marx Creek model to stream discharge was achieved when a NRMSE of $7.1 \%$ was achieved. Ultimately, calibration to hydraulic head and 
Table 1 Comparison of groundwater level (head) values observed in the monitor wells on 18 July 2006 and the model-calculated head values from the final calibration simulation

\begin{tabular}{lllc}
\hline $\begin{array}{l}\text { Well } \\
\text { number }\end{array}$ & $\begin{array}{l}\text { Observed } \\
\text { head }(\mathrm{m})\end{array}$ & $\begin{array}{l}\text { Model-calculated } \\
\text { head }(\mathrm{m})\end{array}$ & $\begin{array}{l}\text { Difference } \\
(\mathrm{m})\end{array}$ \\
\hline Well 1 & 44.31 & 44.40 & 0.09 \\
N2 & 44.58 & 44.85 & 0.27 \\
N3 & 45.09 & 45.22 & 0.13 \\
N4 & 45.29 & 45.55 & 0.26 \\
N5 & 45.55 & 45.85 & 0.30 \\
N6 & 45.67 & 46.14 & 0.48 \\
N7 & 46.06 & 46.42 & 0.36 \\
N8 & 46.74 & 46.68 & -0.06 \\
N9 & 47.06 & 46.97 & -0.10 \\
N10 & 47.71 & 47.26 & -0.45 \\
E2 & 44.26 & 44.00 & -0.26 \\
E3 & 44.15 & 43.35 & -0.81 \\
E4 & 44.14 & 43.44 & -0.70 \\
E5 & 44.14 & 43.55 & -0.58 \\
E6 & 44.24 & 43.64 & -0.59 \\
E7 & 44.46 & 44.08 & -0.38 \\
E8 & 44.74 & 44.06 & -0.68 \\
E9 & 45.03 & 44.56 & -0.48 \\
MC1 & 49.08 & 48.43 & -0.64 \\
MC2 & 48.59 & 47.85 & -0.74 \\
Average & Not applicable & Not applicable & -0.23 \\
\hline & & & \\
\hline
\end{tabular}

stream discharge occurred simultaneously, so the simulation that achieved final calibration to hydraulic head also achieved final calibration to stream discharge. A summary of the stream discharge calibration results is presented in Table 2.

Visual MODFLOW was also used to produce a mass balance of recharge and discharge groundwater fluxes to and from the calibrated model (Table 3). The model's greatest recharge and discharge fluxes were to and from constant-head boundaries. The difference between the model's total recharge-flux volume and discharge-flux volume was $<0.01 \%$.

\section{Addition of extension stream to the model}

The 450-m extension stream was added to the Marx Creek model after calibration to hydraulic head and stream discharge was achieved. The location of the extension stream is shown in Fig. 2. The streambed elevation, width, and length of each segment were based on engineering specifications provided by Robert Gubernick, an engineering geologist for Tongass National Forest (Nelson 2010). Inflow to the furthest upstream stream segment (cell 1) was assigned as $0 \mathrm{~m}^{3} / \mathrm{day}$. All of the extension stream's stream cells were assigned as separate stream segments and zones within the model so that seepage from the groundwater system into individual stream cells could be calculated.

Stream stage elevations in the stream segments were calculated by Visual MODFLOW. This required assigning a Manning's roughness coefficient value to the stream segments, which is often done by comparing the channel of interest to similar channels with known roughness coefficient values (Barnes 1967). Of the 50 stream channel profiles and roughness coefficients compiled by Barnes (1967), it was determined that upper Marx Creek was most comparable to Catherine Creek in Union, Oregon. Upper Marx Creek was determined to be comparable to Catherine Creek because the streambeds of both streams are comprised of cobbles and small boulders, and both streams have small trees and brush lining their banks. The streambed roughness coefficient value of Catherine Creek was 0.043 , so the same value was input to the Marx Creek model's stream segments.

Visual MODFLOW was then used to produce a mass balance of recharge and discharge groundwater fluxes to and from the Marx Creek model, with the extension stream added to the model (Table 3). The model's greatest recharge and discharge fluxes were to and from constant-head boundaries. The difference between the model's total recharge-flux volume and discharge-flux volume was $<0.01 \%$.

\section{Predictive simulations}

The calibrated Marx Creek model was used to run three predictive simulations under steady-state conditions. The purpose of the first simulation was to determine the effect of the extension stream on the site's hydrogeologic system and discharge in upper Marx Creek. This was accomplished by adding the extension stream to the model, as described above, and running the model under steady-state conditions. The second simulation consisted of removing all of upper Marx Creek's stream cells located upstream of its confluence with the extension stream (stream cells 1-14), and leaving the extension stream in the model. The purpose of this simulation was to determine the impact that removing upper Marx Creek would have on discharge in the extension stream, since the Tongass National Forest identified this as a possible course of action. The third simulation was the same as the second simulation, with the exception that groundwater levels were reduced throughout the model by $32 \mathrm{~cm}$ to simulate the minimum groundwater level recorded during the 2006 salmon-spawning season. This was done to determine the effect of a seasonally low groundwater table on discharge in the extension stream.

The first simulation calculated high seepage rates to the extension stream and reduced baseflow to upper 
(a)

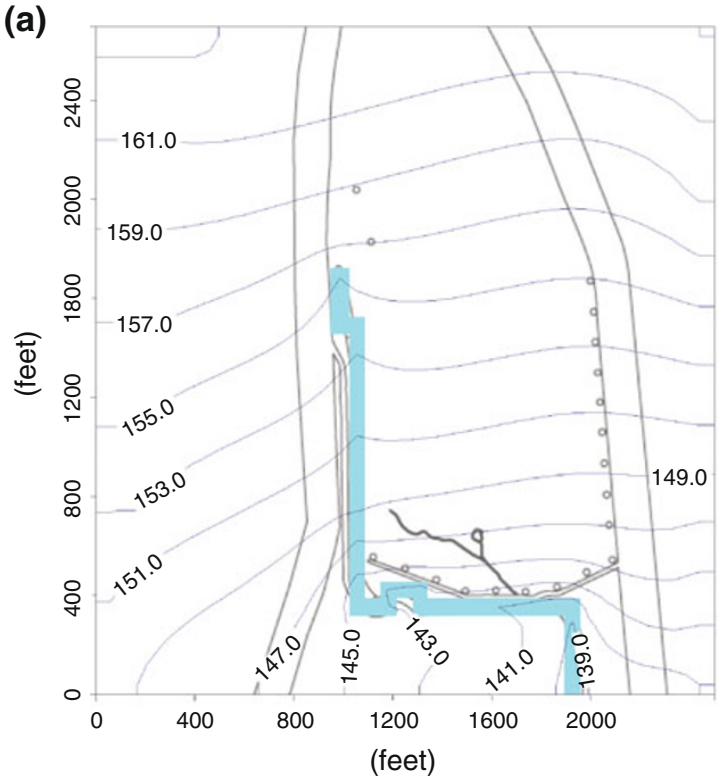

(c)

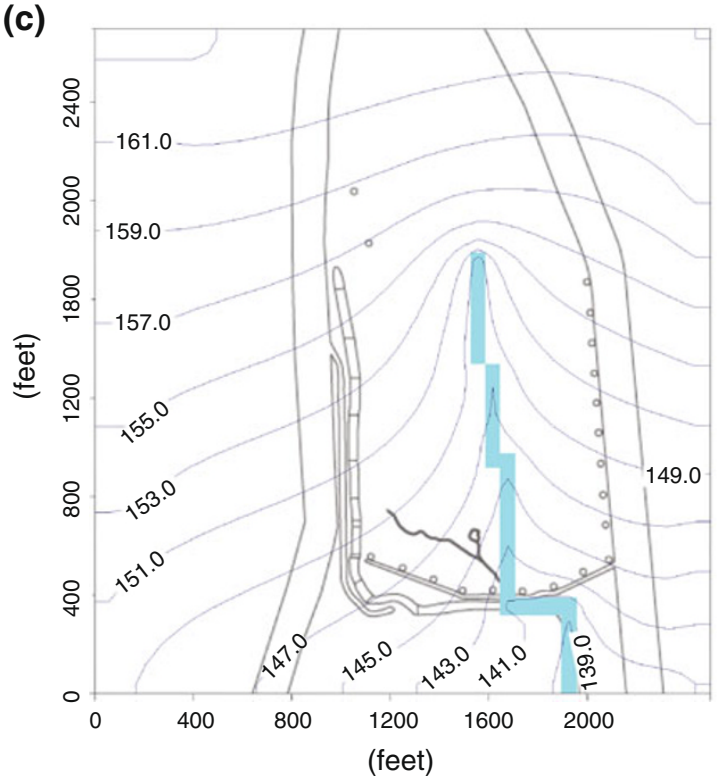

Fig. 4 Groundwater level contour maps generated by the Marx Creek model of a the calibrated Marx Creek model, b the first predictive simulation, $\mathbf{c}$ the second predictive simulation, and $\mathbf{d}$ the

Marx Creek (Table 4). The total calculated flow to upper Marx Creek was reduced by $17 \%$ as a result of the extension stream being added to the model. The model also predicted that total discharge in the extension stream would be three times greater than discharge in approximately the same length of channel (stream cells 1-12) of upper Marx Creek. A water table contour map showing the results of the first predictive simulation is included as Fig. 4b.

The second predictive simulation calculated groundwater flow direction and gradient in the vicinity of the (b)

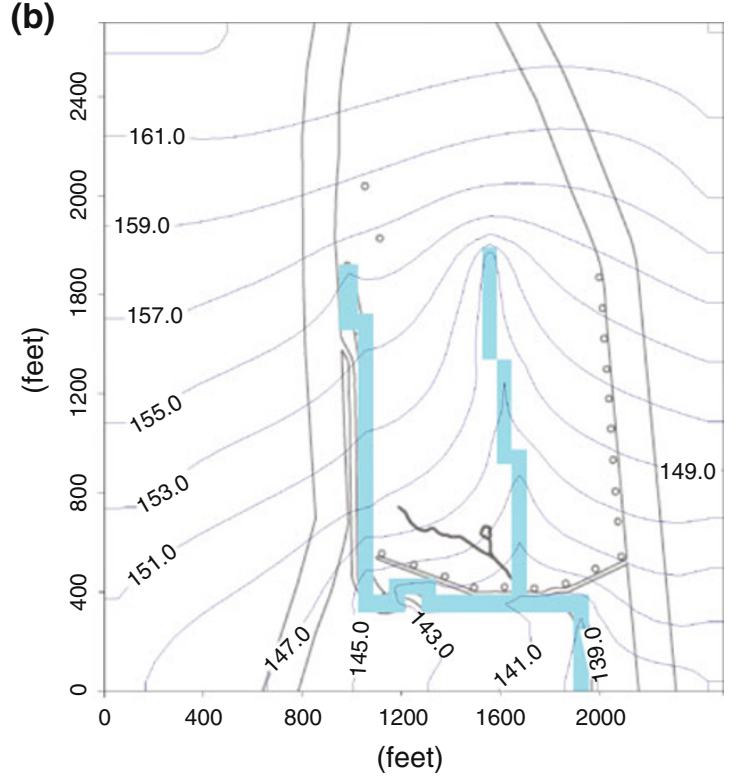

(d)

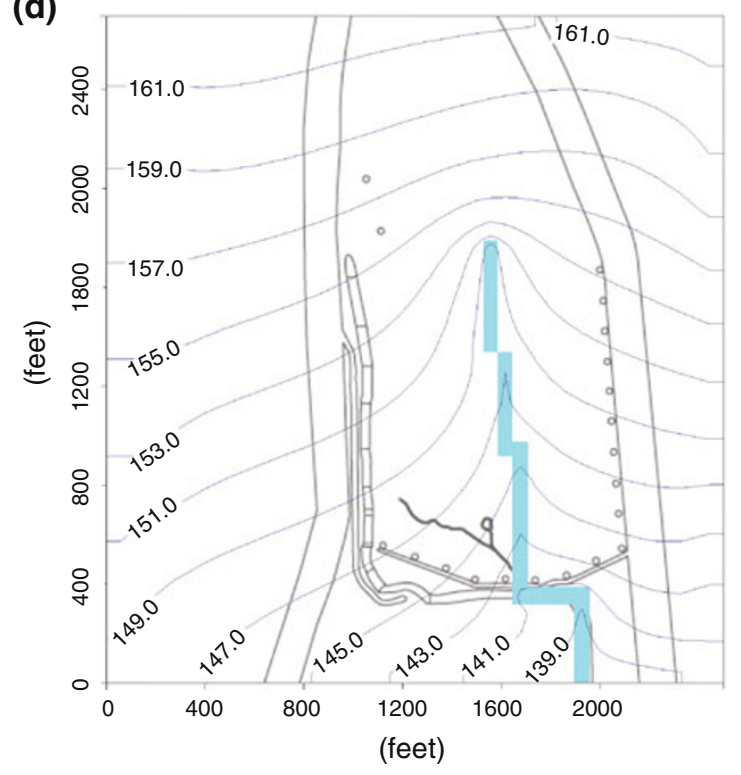

third predictive simulation. Model scales and groundwater level contours are in units of feet

extension stream to be similar to values determined during the first simulation. However, the removal of upper Marx Creek stream cells 1-14 resulted in a $5.0 \%$ increase in baseflow to the extension stream (Table 5). A water-table contour map showing the results of the second predictive simulation is included as Fig. 4c.

The third predictive simulation consisted of reducing groundwater levels throughout the model by $32 \mathrm{~cm}$ to simulate groundwater flow during low water table conditions. This was accomplished by reducing all of the model's constant-head boundary values. Groundwater 
Table 2 Comparison of stream discharge observed in upper Marx Creek on 2 July 2007 and the model-calculated discharge from the final calibration simulation

\begin{tabular}{lllll}
\hline $\begin{array}{l}\text { Stream } \\
\text { cell }\end{array}$ & $\begin{array}{l}\text { Model-calculated } \\
\text { discharge } \\
\left(\mathrm{m}^{3} / \text { day }\right)\end{array}$ & $\begin{array}{l}\text { Discharge measured } \\
\text { in July 2007 } \\
\left(\mathrm{m}^{3} / \text { day }\right)\end{array}$ & $\begin{array}{l}\text { Difference } \\
\left(\mathrm{m}^{3} / \text { day }\right)\end{array}$ & $\begin{array}{l}\text { Percentage } \\
\text { difference }\end{array}$ \\
\hline 1 & 1,331 & 736 & 595 & +81 \\
2 & 2,360 & 1,540 & 820 & +53 \\
3 & 2,949 & 1,265 & 1,684 & +133 \\
4 & 3,669 & 2,401 & 1,268 & +53 \\
5 & 4,314 & 3,557 & 756 & +21 \\
6 & 4,245 & 4,808 & -563 & -12 \\
7 & 4,460 & 6,163 & $-1,704$ & -28 \\
8 & 4,904 & 5,412 & -508 & -9 \\
9 & 5,262 & 5,219 & 43 & +1 \\
10 & 5,836 & 5,455 & 381 & +7 \\
11 & 6,621 & 5,901 & 720 & +12 \\
12 & 8,233 & 6,709 & 1,524 & +23 \\
13 & 11,999 & 7,522 & 4,477 & +60 \\
14 & 17,724 & 20,231 & $-2,507$ & -12 \\
15 & 22,698 & 23,963 & $-1,265$ & -5 \\
16 & 26,388 & Not measured & Not applicable & Not applicable \\
\hline
\end{tabular}

Table 3 Marx Creek model recharge and discharge flux-volumes to and from the groundwater system, prior to and after insertion of the extension stream

\begin{tabular}{|c|c|c|c|c|}
\hline \multirow[t]{2}{*}{ Model boundary } & \multicolumn{2}{|c|}{ Calibrated Marx Creek model without the extension stream } & \multicolumn{2}{|c|}{ Calibrated Marx Creek model with the extension stream } \\
\hline & Recharge flux ( $\mathrm{m}^{3} /$ day) & Discharge flux $\left(\mathrm{m}^{3} /\right.$ day $)$ & Recharge flux ( $\mathrm{m}^{3} /$ day $)$ & Discharge flux $\left(\mathrm{m}^{3} /\right.$ day $)$ \\
\hline Constant-head & 423,200 & 396,810 & 442,590 & 395,110 \\
\hline Stream leakage & 291 & 26,695 & 339 & 47,881 \\
\hline Precipitation & 469 & 0 & 469 & 0 \\
\hline Evapotranspiration & 0 & 440 & 0 & 398 \\
\hline Total & 423,960 & 423,945 & 443,398 & 443,389 \\
\hline
\end{tabular}

levels were reduced by $32 \mathrm{~cm}$ because this was the average fluctuation between the maximum and minimum water levels recorded in the monitor wells from mid-July 2006 to 31 August 2006, which is the time of year when summer-run chum salmon spawning typically occurs (Heinl et al. 2004). Like the second predictive simulation, upper Marx Creek stream cells 1-14 were removed from the model prior to running the third predictive simulation.

The third predictive simulation determined that a $32-\mathrm{cm}$ reduction in the water table would decrease baseflow to the extension stream by $18 \%$ (Table 5). However, the simulation also predicted that stream discharge would remain 2.5 times greater than the field-measured discharge in the equivalent length of upper Marx Creek stream channel (stream cells 1-12), despite the reduction in seepage. A water table contour map showing the results of the third predictive simulation is included as Fig. $4 \mathrm{~d}$.

\section{Conclusions from constructed extension stream}

The extension stream was constructed during the summer of 2008 (USFS 2009). Cobble-sized channel substrate was initially installed in the extension stream, but after observing that chum salmon preferred the finer-grained sections of the stream, the Tongass National Forest excavated the cobble-sized sediment and replaced it with coarse gravelsized sediment (W. Young personal communication November 22, 2011). Additionally, all but $45 \mathrm{~m}$ of upper Marx Creek located upstream from its confluence with the extension stream was decommissioned during the summer of 2010 (W. Young personal communication November 22, 2011). Decommissioning of the stream consisted of infilling the channel with material excavated during construction of the extension stream. The purpose of this was to prevent the formerly turbid water of upper Marx Creek from flowing into further downstream sections of the stream. 
Table 4 Model-calculated discharge of upper Marx Creek and the extension stream from the first predictive simulation

\begin{tabular}{|c|c|c|c|c|c|}
\hline \multicolumn{4}{|c|}{ Upper Marx Creek } & \multicolumn{2}{|c|}{ Extension stream } \\
\hline $\begin{array}{l}\text { Stream } \\
\text { cell }\end{array}$ & $\begin{array}{l}\text { Total discharge without } \\
\text { extension }\left(\mathrm{m}^{3} / \text { day }\right)\end{array}$ & $\begin{array}{l}\text { Total discharge with } \\
\text { extension ( } \mathrm{m}^{3} / \text { day) }\end{array}$ & $\begin{array}{l}\text { Percentage } \\
\text { change }\end{array}$ & $\begin{array}{l}\text { Stream } \\
\text { cell }\end{array}$ & $\begin{array}{l}\text { Total discharge } \\
\left(\mathrm{m}^{3} / \text { day }\right)\end{array}$ \\
\hline 1 & 1,331 & 1,097 & -18 & Ext. 1 & 7,269 \\
\hline 2 & 2,360 & 1,740 & -26 & Ext. 2 & 15,157 \\
\hline 3 & 2,949 & 2,125 & -28 & Ext. 3 & 16,593 \\
\hline 4 & 3,669 & 2,565 & -30 & Ext. 4 & 18,652 \\
\hline 5 & 4,314 & 3,006 & -30 & Ext. 5 & 19,233 \\
\hline 6 & 4,245 & 2,776 & -35 & Ext. 6 & 21,117 \\
\hline 7 & 4,460 & 2,948 & -34 & Ext. 7 & 22,743 \\
\hline 8 & 4,904 & 3,361 & -31 & Ext. 8 & 23,331 \\
\hline 9 & 5,262 & 3,693 & -30 & Ext. 9 & 24,671 \\
\hline 10 & 5,836 & 4,253 & -27 & & \\
\hline 11 & 6,621 & 5,033 & -24 & & \\
\hline 12 & 8,233 & 6,643 & -19 & & \\
\hline 13 & 11,999 & 10,222 & -15 & & \\
\hline 14 & 17,724 & 14,636 & -17 & & \\
\hline
\end{tabular}

Table 5 Comparison of discharge values in the extension stream, as predicted by the Marx Creek model, from the first, second and third predictive simulations

\begin{tabular}{llllll}
\hline $\begin{array}{l}\text { Stream } \\
\text { cell }\end{array}$ & $\begin{array}{l}\text { First } \\
\text { simulation } \\
\left(\mathrm{m}^{3} / \text { day }\right)\end{array}$ & $\begin{array}{l}\text { Second } \\
\text { simulation } \\
\left(\mathrm{m}^{3} / \text { day }\right)\end{array}$ & $\begin{array}{l}\text { Third } \\
\text { simulation } \\
\left(\mathrm{m}^{3} / \text { day }\right)\end{array}$ & $\begin{array}{l}\text { Percentage } \\
\text { change between } \\
\text { first and second } \\
\text { simulations }\end{array}$ & $\begin{array}{l}\text { Percentage } \\
\text { change between } \\
\text { second and third } \\
\text { simulations }\end{array}$ \\
\hline Ext. 1 & 7,269 & 7,328 & 6,415 & +0.8 & -12 \\
Ext. 2 & 15,157 & 15,347 & 13,030 & +1.3 & -15 \\
Ext. 3 & 16,593 & 16,823 & 14,138 & +1.4 & -16 \\
Ext. 4 & 18,652 & 18,949 & 15,781 & +1.6 & -17 \\
Ext. 5 & 19,233 & 19,553 & 16,201 & +1.7 & -17 \\
Ext. 6 & 21,117 & 21,517 & 17,778 & +1.9 & -17 \\
Ext. 7 & 22,743 & 23,301 & 19,157 & +2.5 & -18 \\
Ext. 8 & 23,331 & 24,024 & 19,675 & +3.0 & -18 \\
Ext. 9 & 24,671 & 25,896 & 21,146 & +5.0 & \\
\hline
\end{tabular}

Quantitative measurements of stream discharge, stream stage, and water depth in the extension stream have not yet been collected (W. Young personal communication 28 May 2013). However, Mr. Will Young, the Tongass National Forest's Supervisory Fisheries Biologist, stated that discharge in the extension stream appears to be comparable to or greater than that of the former upper Marx Creek, and that stream stage appears to be comparable to that of the former Marx Creek (W. Young personal communication 22 November 2011). Additionally, a survey of the field site conducted in August 2009 revealed that suspended silt was not visible in the water of the extension stream (USFS 2009). Mr. Young stated during a phone conversation that water in the extension stream has remained significantly clearer than that of the former upper Marx Creek (W. Young personal communication 22 November 2011). He said that there remains a minor amount of suspended silt in the remaining 45-m segment of upper Marx Creek, but that silt levels are not high enough to necessitate decommissioning this channel segment.

Chum salmon counts were conducted in Marx Creek 2 to 16 times every summer since 1986 by the Alaska Department of Fish and Game. Chum salmon count numbers were at or below the historical median for the past 6 years, based on unpublished chum salmon count data provided by Mr. Steve Heinl, an Alaska Department of Fish and Game fisheries biologist (S. Heinl unpublished salmon count data 6 June 2013). Since 1986, the median number of salmon counted in Marx Creek is 1,223 fish, and the mean is 3,370 fish. However, since 2007, the median number of salmon counted in Marx Creek was 243 fish, and the mean was 420 fish. According to Mr. Heinl, the reason for the reduction in chum salmon using Marx Creek is unknown, as other nearby salmon-spawning streams that 
drain to the Portland Canal have been productive over the past 4 years ( $S$. Heinl personal communication 5 June 2013). Ongoing study of this problem is occurring in an attempt to determine the cause of the salmon reduction in Marx Creek.

The reduction in the number of salmon using Marx Creek has impacted the extension stream, as salmon-use in the stream has been quite low (S. Heinl personal communication). Since its construction in 2008, the maximum number of chum salmon counted in the extension stream was 27 fish in 2010 (S. Heinl unpublished salmon count data 6 June 2013). However, there were no salmon observed in the extension stream during the most recent salmon count, which was conducted during the summer of 2012.

The low number of chum salmon observed in the extension stream may be the result of Marx Creek not being fully utilized, resulting in salmon not needing to travel to the upper reaches of the stream (USFS 2009). It has also been hypothesized that low water temperatures, lack of habitat complexity, and/or high levels of fine sediment in the streambed may be preventing salmon from using the extension stream. Habitat improvement actions have recently been proposed by the Tongass National Forest to address these concerns, and a draft environmental assessment has recently been completed (USFS 2013). Habitat improvement actions on the extension stream include: (1) enlarging and increasing the surface area of a small pond at the headwaters of the extension stream to increase solar input, thereby increasing water temperature; (2) rehabilitate the steam banks through revegetation and slope enhancement, thereby providing greater habitat complexity; and (3) reduce fine sediment in up to $9,810 \mathrm{~m}^{2}$ of spawning gravels via suction dredge (USFS 2013). The Tongass National Forest hopes to initiate work on these improvements during the summer of 2014 (S. Heinl personal communication 5 June 2013).

\section{Conclusions}

A three-dimensional groundwater flow model of the Marx Creek site was created based on field-measured upper Marx Creek stream discharge and stream channel dimensions, and on groundwater-level data. The model was manually calibrated to upper Marx Creek stream discharge and site groundwater levels. The model was used to predict baseflow to an extension stream that was designed to branch off from upper Marx Creek, and had not yet been constructed at the time of model creation.

The Marx Creek model predicted that discharge in the extension stream would be greater than field-measured discharge in stream cells 1-14 of upper Marx Creek, despite the channel length of the extension stream being shorter and the channel width comparable. Additionally, the model predicted that removing stream cells 1-14 of upper Marx Creek would increase the discharge in the extension stream by approximately $5 \%$. The third and final model simulation predicted that a $32-\mathrm{cm}$ decline in groundwater levels would result in an $18 \%$ reduction in baseflow to the extension stream, although discharge would remain 2.5 times greater than the field-measured discharge in the equivalent length of upper Marx Creek stream channel.

Based on predictions made by the Marx Creek model, the Tongass National Forest determined that with proper weir construction and placement it would be possible to generate water depths in the extension stream that would support chum salmon-spawning. The extension stream was constructed during the summer of 2008, and during the summer of 2010 all but $45 \mathrm{~m}$ of upper Marx Creek located upstream from its confluence with the extension stream was decommissioned to prevent silty water from flowing into further downstream sections of the stream.

Although neither stream discharge nor stream stage have been measured in the extension stream since its construction, it was observed that discharge and stream stage are comparable to or greater than discharge in the former upper Marx Creek. It was also observed that constructing the extension steam further from the Salmon River flood-control dike substantially reduced the amount of silt in the stream.

The number of chum salmon in Marx Creek has been well-below average over the past 6 years. The reason for this is unknown, as nearby salmon-spawning streams were productive the past 4 years. Salmon use in the extension stream has also been extremely low since its construction. A significant reason for this may be that salmon are not traveling to the upper reaches of the stream because the lower reaches are not being fully utilized. It was also hypothesized that low water temperatures, lack of habitat complexity, and/or high levels of fine sediment in the streambed may be preventing salmon from using the extension stream. Habitat improvement of the extension stream and ongoing study of both Marx Creek and the extension stream are planned for the future. The Tongass National Forest and Alaska Department of Fish and Game hope that these actions will reestablish Marx Creek, and establish the extension stream, as productive salmonspawning streams.

Acknowledgments Funding for this project was provided by the Pacific Salmon Commission to Utah State University, through the Marx Creek Challenge Cost Share Agreement 06CS-11100500-101. The authors would like to thank Robert Gubernick, Carol Denton, Todd Tisler, and Will Young of the Tongass National Forest for their valuable assistance and/or information that they provided. We would also like to thank Kevin Randall, who was then a graduate student in 
geology at Utah State University, for performing much of the initial field-data collection. Finally, we would like to thank Steve Heinl of the Alaska Department of Fish and Game for providing data on salmon counts conducted in Marx Creek.

Open Access This article is distributed under the terms of the Creative Commons Attribution License which permits any use, distribution, and reproduction in any medium, provided the original author(s) and the source are credited.

\section{References}

Anderson MP, Woessner WW (2002) Applied groundwater modeling: simulation of flow and advective transport. Elsevier, San Diego

Back W, Rosenshein JS, Seaber PR (eds) (1988) Hydrogeology-the geology of North America, vol 0-2. The Geological Society of America, Boulder, Colorado

Barnes HH Jr (1967) Roughness characteristics of natural channels. US Geological Survey water supply paper 1849

Buddington AF (1929) Geology of hyder and vicinity, southeastern Alaska, with a reconnaissance of Chickamin River. US Geological Survey bulletin B-0807

Denton C (1997) Marx Creek spawning channel evaluation, final report. CFMD Division, Alaska Department of Fish and Game, Ketchikan

Flint RF (1957) Glacial and pleistocene geology. Wiley, New York

Heath RC (1983) Basic ground-water hydrology. US Geological Survey water supply paper 2220
Heinl SC, Zadina TP, McGregor AJ, Geiger HJ (2004) Chum salmon stock status and escapement goals in Southeast Alaska. In: Geiger HJ, McPherson S (eds) Stock status and escapement goals for salmon stocks in southeast Alaska, Divisions of Sport Fish and Commercial Fisheries, Alaska Department of Fish and Game, special publication 04-02

Johnson AI (1967) Specific yield-compilation of specific yields for various materials. US Geological Survey water supply paper 1662-A

McDonald MG, Harbaugh AW (1988) A modular three-dimensional finite-difference ground-water flow model. US Geological Survey techniques of water resources investigations report book 6 , chapter A1, p 528

Nelson $\mathrm{T}$ (2010) Feasibility of extending an artificial salmon spawning stream, Marx Creek near Hyder, Alaska. M.S. Thesis, Utah State University

Patric J, Black P (1968) Potential evapotranspiration and climate in Alaska by Thornthwaite's classification. US Department of Agriculture Forest Service research paper PNW-71

Todd DK (1980) Groundwater hydrology, 2nd edn. Wiley, New York

US Forest Service (USFS) (2009) Marx Creek rehabilitation. Ketchikan-Misty Fjords Ranger District

US Forest Service (USFS) (2013) Marx Creek habitat enhancement draft environmental assessment. Ketchikan-Misty Fjords Ranger District

Waterloo Hydrogeologic, Inc. (2006) Visual MODFLOW version 4.2. Waterloo 